\title{
BIOLOGI KOMUNIKASI MELALUI IMPLEMENTASI TEKNOLOGI INFORMASI MENUJU AKSELERASI PEMBELAJARAN *
}

Oleh : Deni Darmawan **

\section{Abstrak}

Biologi Komunikasi merupakan cabang IImu Komunikasi yang memiliki bidang garapan khusus terhadap upaya-upaya penjelasan mengenai fenomena dibalik fenomena psikologi. Bidang garapan ini sangat penting untuk lebih banyak dikaji secara mendalam khususnya melalui penelitian-penelitian yang sifatnya eksperimental/laboratorium. Sehingga Biologi Komunikasi ini dapat menjadi Mata Kuliah Khusus pada Program Studi Komunikasi di kemudian hari.

Salah satu temuan yang sangat penting dari penelitian, yaitu ditemukannya bukti mengenai perilaku biologi komunikasi yang terjadi di dalam otak manusia, dalam hal ini peserta didik. Perilakuperilaku tersebut ditunjukkan melalui bukti-bukti proses komunikasi yang dilakukan oleh bagian-bagian spesifik otak ( Frontal (F); Temporal (T); Parasagital (P); Occipital (Oc); dan Central (C)) khususnya ketika peserta didik melakukan aktivitas belajar dalam bentuk mengamati, memahami, mendengar, dan melakukan kecenderungan bertindak. Masing-masing bagian spesifik otak tersebut melakukan transfer informasi yang berasal dari luar individu, khususnya stimulus yang dikemas dalam bentuk media yang berbasis Teknologi Informasi, sebagaimana yang banyak ditemui dalam bentuk model-model pembelajaran dewasa ini ( Computer Based Instruction : Drill, Tutorial, Simulasi, dan Permainan); ataupun yang dikemas dengan pemanfaatan ICT ((Information Communication and Technology) di sekolah-sekolah.

*) Tulisan ini berisi temuan dari penelitian Disertasi Bidang Kajian IImu Komunikasi di Universitas Padjadjaran Bandung tahun 2006.

**) Dr. Deni Darmawan, S.Pd., M.Si., adalah Dosen Universitas Pendidikan Indonesia (UPI) Bandung, Konsultan Research. (E-mail: diestry2005@yahoo.com ) 
Temuan penelitian ini secara praktis bisa diaplikasikan pada kelompok bidang studi sosial maupun bidang eksakta mulai jenjang Sekolah Dasar sampai dengan Pendidikan Tinggi.

\section{A. PENDAHULUAN}

Berdasar pengamatan terhadap fenomena nyata di beberapa lembaga pendidikan mulai dari jenjang Pendidikan Dasar sampai Pendidikan Tinggi menunjukkan bahwa aspek pengembangan dan adopsi terhadap teknologi Informasi dan Komunikasi masih berbeda-beda kemampuan dan hasil yang diperolehnya. Khususnya dalam dunia pendidikan selama ini umumnya tidak dilakukan berdasarkan analisis kemampuan berpikir, kreativitas dan studi-studi pengoptimalan kemampuan otak kiri dan otak kanan para pengguna terutama peserta didik. Dari hasil pengamatan dan pengalaman selama ini pemanfaatan dan desain pembelajaran berbasis teknologi informasi dan komunikasi tidak diiringi dan disesuaikan dengan hasil penelitian mengenai pemberdayaan kemampuan belajar peserta didik.

Inovasi yang dilakukan dari kasus-kasus lembaga pendidikan pengalaman empirik penulis di Bandung masih dalam satu sudut pandang, yaitu pemanfaatan teknologi informasi dan komunikasi dalam pembelajaran. Sebagai contohnya banyak pembelajaran menggunakan model pembelajaran berbasis komputer, yaitu informasi pelajaran yang disampaikan dikemas dalam bentuk program interaktif komputer. Padahal pemanfaatan tersebut belum tentu sesuai dan didukung oleh kondisi atau perilaku biologis peserta didik terutama kemampuan otak kiri dan otak kanannya. Kecenderungan di lapangan pemanfaatan teknologi informasi ini masih dalam rangka trend pembelajaran modern saja. Fenomena seperti ini mengakibatkan munculnya dilema bahwa hasil proses pembelajaran tidak mencapai kualitas yang diinginkan, padahal guru sudah berusaha membuat program pembelajaran yang bagus dan mahal dengan fasilitas media dan alat yang modern. 
Banyak faktor dalam keberhasilan suatu proses dan hasil pembelajaran tersebut jika dilihat secara utuh dari landasan ilmiah dan pendekatan ilmu pendidikan. Jelasnya bahwa dalam praktek pendidikan selama ini belum menyentuh analisis kebutuhan perilaku peserta didik secara biologis terutama analisis pemberdayaan secara seimbang antara otak kiri dan otak kanan. Inilah yang menjadi inti dari masalah telaah terhadap hakikat dibalik perilaku yang nampak, di mana secara psikologis ketika belajar siswa yang dimaksud kelihatan memperhatikan dan mengamati semua penjelasan guru, akan tetapi guru tersebut tidak tahu bagaimana dibalik prilaku yang nampak yang dialami siswa tersebut.

Di sisi lain telaah fenomena komunikasi yang terjadi dalam tubuh manusia yang dikontrol oleh bagian spesifik otak, baik pada belahan otak kiri maupun otak kanan sehingga menjadi suatu perilaku yang kompleks masih belum banyak dianalisis dalam ilmu komunikasi. Sebagaimana dinyatakan oleh salah satu pendapat ahli bahwa semua daerah dalam otak baik otak kiri dan kanan melakukan komunikasi ketika perilaku kompleks ditunjukkan manusia, (Chauchard, 1983:41). Perilaku kompleks inilah yang diharapkan mampu dicapai oleh peserta didik terutama ketika mereka mengikuti pembelajaran berbasis teknologi informasi dan komunikasi. Perilaku kompleks ini tentunya didukung oleh kemampuan berpikir, kepekaan terhadap perasaan, kemampuan kognitif, afektif dan psikomotor yang akan tercapai jika proses pembelajaran yang dialami mendukung.

Penelitian ini bertujuan menemukan gambaran fakta empiris secara holistik dan teruji mengenai biologi komunikasi otak kiri dan otak kanan peserta didik melalui implementasi teknologi informasi dalam pembelajaran berdasarkan perspektif komunikasi, pendidikan, psikologi, kedokteran, budaya dan teknologi informasi untuk mempercepat pembelajaran pada tingkat pendidikan dasar sampai pendidikan tinggi. Secara khusus penelitian ini bertujuan untuk:

1. Menemukan bagaimana pengaruh pengemasan informasi pembelajaran dalam bentuk model pembelajaran berbasis teknologi informasi terhadap kecepatan belajar siswa yang 
dikontrol oleh kondisi biologi komunikiasi otak pada bidang sosial dan eksakta pada jenjang pendidikan dasar, menengah dan pendidikan tinggi.

2. Menemukan, menganalisis dan menjelaskan perilaku biologi komunikasi yang terjadi pada otak peserta didik ketika melakukan kegiatan mengamati, merasa, memahami dan kecenderungan bertindak saat sebelum dan sesudah memperoleh informasi pembelajaran berbasis teknologi informasi pada tingkat pendidikan dasar, menengah dan pendidikan tinggi dalam bidang eksakta dan sosial.

3. Menganalisis perspektif pendidikan, komunikasi, psikologi, kedokteran, budaya dan teknologi Informasi terhadap fenomena perilaku biologi komunikasi otak yang dialami peserta didik pada proses menerima, mentransformasi dan mengolah informasi pembelajaran berbasis teknologi informasi pada jenjang pendidikan dasar, menengah dan pendidikan tinggi menuju akselerasi belajar.

4. Menganalisis model pembelajaran berbasis teknologi informasi dan komunikasi yang mampu memberikan optimalisasi proses perilaku biologi komunikasi otak dalam akselerasi pembelajaran peserta didik pada tingkat pendidikan dasar, menengah, dan tinggi untuk bidang sosial dan eksakta.

\section{B. KERANGKA PEMIKIRAN}

Perkembangan ilmu komunikasi akan terus berlanjut dan diantaranya berdasarkan atas hasil adopsi dan inovasi, salah satunya didasarkan atas hasil pemikiran dari adopsi teknologi komunikasi yang dikemukakan oleh Rogers, (1986:116).

Mengenai inovasi ini, Litlejohn (1996:137) mengkajinya melalui Information-Integration Theory, yaitu bagaimana informasi diorganisasi dan diperlakukan serta bagaimana informasi tersebut mempengaruhi sistem kognitif. Jika ditinjau dari ilmu biologi maka analisis terhadap otak ini memerlukan landasan telaah ilmu-ilmu alam lainnya seperti ilmu fisika dan matematika. Jika kembali kepada upaya 
pemberdayaan kemampuan otak manusia dalam melakukan komunikasi maka Applbaum (1973) mengemukakan salah satu landasan utamanya yang berhubungan dengan Fundamental Concept in Human Communication, dijelaskan bahwa: "Analisis terhadap perilaku manusia yang muncul akan memberikan kajian secara mendalam terhadap proses komunikasi interpersonal dan komunikasi intrapersonal.". Salah satu kajian ilmu komunikasi dari sudut pandang teoritis yang berkenaan terhadap pehatian penggunaan biologi dalam menganalisis proses komunikasi manusia diantaranya dalam Interpersonal Communication Book yang dituliskan oleh Devito,(1989: 267-269), dijelaskan bahwa: "Perilaku biologi komunikasi yang ditampilkan cenderung kepada hasil hubungan antara individu dengan individu lainnya dalam lingkungan sosial: " the process of sending and receiving messages between two persons, or among a small group, with some effect and some immediate feedback)."

Berdasarkan uraian di atas selanjutnya dapat ditelaah kembali mengenai salah satu akar dari komunikasi adalah Biologi (ICA, 20002002), di mana Winangsih, (2001:18-19), mengembangkannya dalam bentuk pohon komunikasi. Secara praksis biologi komunikasi dalam hal ini analisisnya ditujukan pada telaah proses interaksi antar individu mulai dari interaksi antar organ tubuh individu yang dikontrol oleh otaknya. Telaah komunikasi secara biologi, khususnya yang terjadi pada otak manusia di antaranya dapat pula dianalisis secara intra mengenai bahasa yang ditunjukkan oleh individu. Bahasa adalah sistem tak terbatas dari tanda-tanda dengar dan lihat yang digunakan manusia untuk berkomunikasi (Pope, 1989:400).

Salah satu teori belajar yang melandasasi dalam upaya penerapan teknologi dalam pembelajaran ini di antaranya teori kognitif yang dikembangkan oleh Gagne (1985:76-77), melalui structure dan process sebagai berikut : structure receptor, short term dan long term memory storage, retrieval, response organization, performance feedback form effector and reiforcement. Pendapat ini diasumsikan memberikan penjelasan terhadap pengkondisian stimulus-respon, sebagaimana dikemukakan oleh Hall (1993:115) bahwa: "Melalui 
faham Psikologi Konstitusi Sheldon yang menggunakan Orientasi Biologis dan Genetik-nya dalam melakukan proses kognitif sehingga diperoleh pemahaman secara menyeluruh." Dengan demikian hasilnya diharapkan mampu menjawab tantangan dari International Communication Association (ICA, 1995) yaitu Instructional/ Developmental Communication; dan Divission and Communication in the National Communication Association (NCA, 1995), yaitu Instructional Development dalam Web Site ICA (Craig, (2004:1). Dengan demikian bagaimana ilmu komunikasi, biologi, psikologi, pendidikan dan teknologi informasi mampu terlihat dalam perilaku komunikasi manusia secara intra maupun inter.

Adapun analisis terhadap proses biologi komunikasi terletak pada pemrosesan informasi yang terjadi pada memori. Kondisi biologis tetap akan memberikan kontribusi dalam pengukuran dan pengotomatisan keseimbangan pemrosesan informasi sebagai dalam bentuk stimulus yang datang. Gagne (1985:77) mengilustrasikannya dalam Essential of learning for instruction, sebagai berikut: Stimulus yang datang dari lingkungan tertentu (environment) yang memberikan stimulus kemudian diterima receptor hingga mampu menyampaikannya pada sensory register dan disimpan pada shortterm memory atau long term memory, yang pada akhirnya diteruskan kepada response generator sebagai tujuan sementara menuju effectors yang akan menunjukkan kecenderungan respon.

Berdasarkan pendapat tersebut maka bentuk bahan belajar dapat disajikan dalam program-program pembelajaran berbasis teknologi informasi, yaitu dikemas dalam bentuk software pembelajaran. Secara lebih rinci Petterson (1993) dalam Plomp (1996:178) menyusun ringkasan prinsip umum disain pesan pembelajaran antara lain sebaiknya memenuhi persyaratan sebagai berikut: (a) penyampaian informasi yang relevan sesuai dengan prasyarat yang diperlukan (recall relevant prerequisite information); (b) mengorganisasikan bahan belajar dan rancangan penyajiannya (organize content and present organizer); (c) menyusun bahan belajar dari sederhana ke kompleks ( progress from simple to complex); (d) 
penyajian informasi yang beragam (variety information peresented); dan (e) menyajikan contoh-contoh (present examples and nonexamples).

Dalam hal ini Rogers, (1986: 55) menjelaskan pula bahwa :"Interaksi pembelajaran merupakan suatu proses yang dinamis dengan mempertimbangkan dua hal, yaitu proses komunikasi itu sendiri dan perlunya saling pengertian untuk mencapai hasil belajar yang diharapkan."

Sebagaimana yang dirumuskan dalam pertanyaan penelitian ini maka kajiannya akan dianalisis perspektif dari keilmuan pendidikan, komunikasi, psikologi, kedokteran/ biologi dan teknologi informasi terhadap apa yang menjadi fokus penelitian yang telah dirumuskan. Persepsi dikemukakan oleh Rahmat, (1999:51) yaitu sebagai pengalaman tentang objek, peristiwa, atau hubungan-hubungan yang diperoleh dengan menyimpulkan informasi dan menafsirkan pesan. Persepsi dari pakar keilmuan tersebut diharapkan mampu mampu menjelaskan dan mendukung kondisi budaya pembelajaran yang di terjadi di lingkungan pendidikan. Budaya pembelajaran yang mampu memberikan kesempatan adaptasi bagi semua pihak yang terkait didalamnya diasumsikan sangat dibutuhkan dewasa ini. Pembelajaran yang dimaksud yaitu pembelajaran yang mampu menyeimbangkan dan memberdayakan kemampuan kerja otak kiri dan otak kanan, sebagaimana yang dikemukakan oleh Shahib (2003:98-101), yaitu proses pembelajaran yang mampu menampakkan adanya keterkaitan antara logik, emosi (perasaan), dan fisik bertahap sesuai sistem memori, mampu mengandalkan pikiran logik dan kritis yang bermotivasi kreativitas. Lebih lanjut Shahib, (2003:141) menjelaskan bahwa perasaan atau emosi yang terdapat pada otak kanan ini mampu mempengaruhi otak kiri dan mengendalikan seluruh perilaku otak manusia, seperti motivasi, mengelola informasi, yakin diri, kekuatan pribadi dan berpikir inovatif. Berdasarkan uraian di atas, maka alur pikir dalam penelitan ini sebagai berikut: 


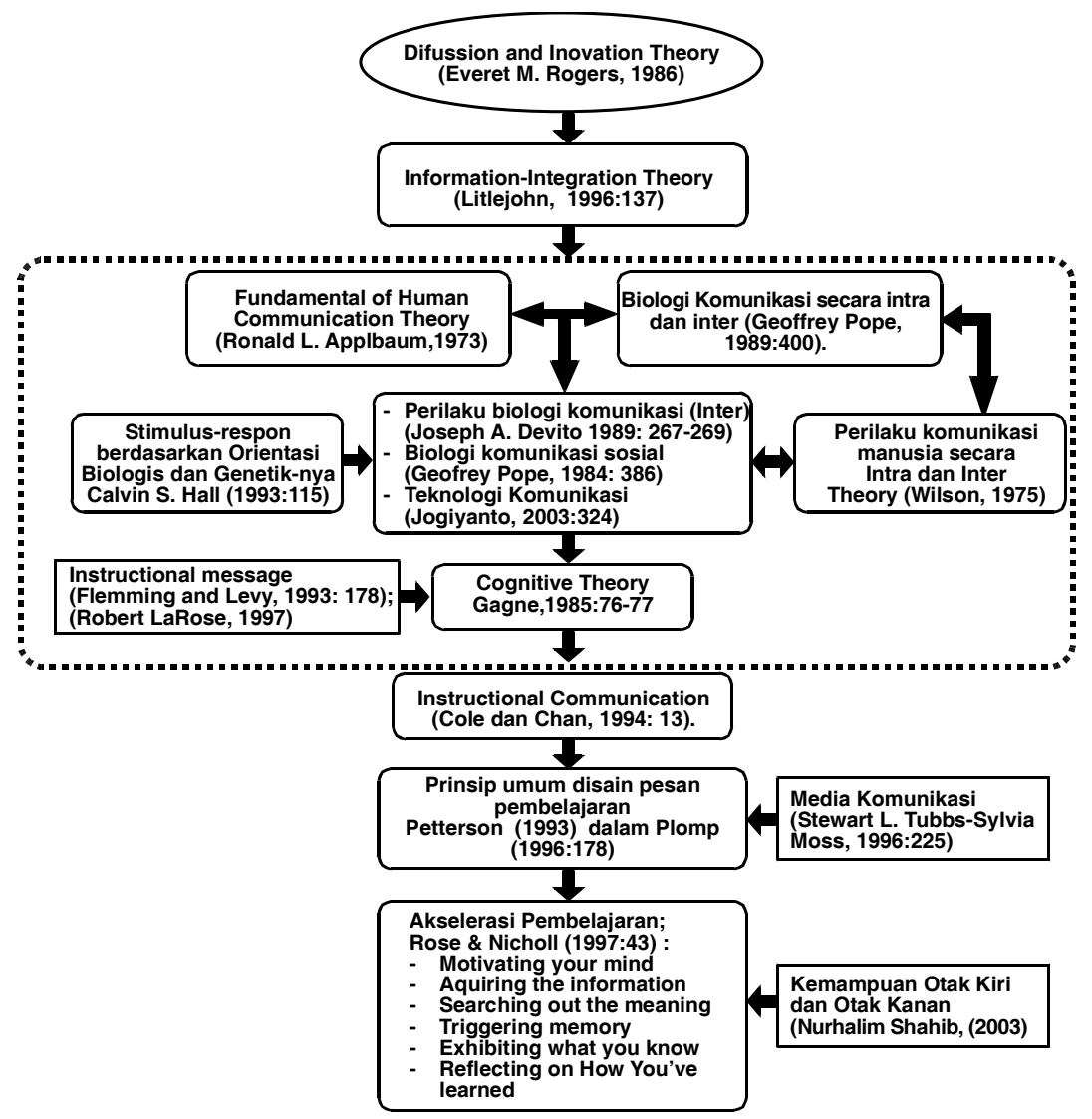

\section{METODE PENELITIAN}

Penelitian ini menggunakan metode eksperimen kuasi, eksperimen laboratorium, dan survey explanatory. Dilaksanakan di Sekolah Dasar sampai dengan Pendidikan di Bandung dengan teknik sampel Cluster Sampling.Teknik pengumpulan data menggunakan instrumen wawancara, observasi, dan focuss group disscussion, survei eksplanasi, eksperimen kuasi, dan eksperimen Laboratorium EEG, kuesioner, soal tes kemampuan otak kiri dan kanan, serta pedoman pemeriksaan EEG. Analisis data dilakukan dengan menggunakan 
teknik yang disesuaikan berdasarkan karakteristik dan jenis data (skala) baik itu dengan metode statistik, maupun kualitatif serta pengukuran alat laboratorium syaraf dan bedah otak.

D. HASIL PENELITIAN DAN PEMBAHASAN

1. Pengaruh pengemasan informasi terhadap kecepatan belajar siswa yang dikontrol oleh kondisi biologi komunikasi otak.

a. Pengaruh Pengemasan Informasi Pembelajaran Terhadap Percepatan Belajar yang dikontrol oleh Biologi Komunikasi Otak

Tabel 1. Hasil Pengujian Percepatan, Ketepatan dan Kemampuan Otak Peserta didik

\begin{tabular}{|c|c|l|}
\hline No & $\begin{array}{c}\text { Jenjang } \\
\text { Pend. }\end{array}$ & \multicolumn{1}{c|}{ Hasil Penelitian } \\
\hline 1. & SD & $\begin{array}{l}\text { Pembelajaran dengan PBTIK pada kelompok sosial dan } \\
\text { eksak mulai peserta didik SD-PT lebih cepat daripada } \\
\text { pembelajaran NONPBTIK.Skor ketepatan menjawab tes } \\
\text { kemampuan Analisis dan Sintesis yang dikontrol oleh } \\
\text { biologi komunikasi melalui PBTIK lebih tinggi dari pada Non } \\
\text { PBTIK pada tes kemampuan Analisis dan Sintesis mulai } \\
\text { SD-PT pada bidang eksakta dan sosial. } \\
\text { Kemampuan otak kiri dan kanan dengan PBTIK lebih tinggi } \\
\text { rata-ratanya daripada otak kiri dan kanan NonPBTIK } \\
\text { pada eksak dan sosial } \\
\text { Analisis otak kiri pada kelompok eksak lebih tinggi rata- } \\
\text { ratanya daripada analisis otak kiri kelompok sosial. } \\
\text { Sintesis otak kanan kelompok eksak lebih tinggi rata- } \\
\text { ratanya daripada sintesis otak kanan kelompok sosial. } \\
\text { Analisis-Otak Kiri-Sosial-SDNONPBTIK lebih kecil } \\
\text { kemampuannya daripada Sintesis-Otak-Kanan-Sosial- } \\
\text { SDNONPBTIK } \\
\text { Analisis-Otak Kiri Sosial-SDPBTIK lebih kecil kemampuan } \\
\text { Sintesis-Otak Kanan Sosial-SDPBTIK }\end{array}$ \\
\hline
\end{tabular}




\begin{tabular}{|c|c|l|}
\hline No & $\begin{array}{c}\text { Jenjang } \\
\text { Pend. }\end{array}$ & \multicolumn{1}{c|}{ Hasil Penelitian } \\
\hline 2. & SMP & $\begin{array}{l}\text { Analisis-Otak Kiri-Eksak-SDNONPBTIK lebih tinggi daripada } \\
\text { Sintesis-Otak-Kanan-Eksak-SDPNONPBTIKc. } \\
\text { Analisis-Otak Kiri-Eksak-SDPBTIK lebih kecil daripada } \\
\text { Sintesis-Otak Kanan-EksakSDPBTI }\end{array}$ \\
\hline $\begin{array}{l}\text { Analisis Otak Kiri-Sosial-SMPNONPBTIK lebih rendah } \\
\text { daripada Analisis-Otak-Kiri-Sosial-SMPPBTIK } \\
\text { Analisis-Otak Kiri-eksak-SMPNONPBTIKAnalisis Otak-Kiri- } \\
\text { Eksak-SMPPBTIK } \\
\text { Analisis-Otak Kiri-eksak-SMPNONPBTIK lebih rendah dari } \\
\text { Analisis Otak-Kiri-Eksak-SMPPBTIK } \\
\text { Sintesis-Otak Kanan-Sosial-SMPNONPBTIK Iebih rendah } \\
\text { daripada Sintesis-Otak-Kanan-Sosial-SMPPBTIK } \\
\text { Sintesis-Otak-Kanan-Eksak-SMPNONPBTIK lebih rendah } \\
\text { daripada Sintesis-Otak Kanan-EksakSMPPBTIK } \\
\text { Analisis-Otak-Kiri-Sosial-SMPPBTIK lebih rendah daripada } \\
\text { Analisis-Otak Kiri-Eksak-SMPPBTIK } \\
\text { Sintesis-Otak-Kanan-Sosial-SMPPBTIK lebih rendah } \\
\text { daripada Sintesis-Otak Kanan-EksakSMPPBTIK } \\
\text { Analisis Otak Kiri-Sosial-SMPNONPBTIK lebih rendah } \\
\text { daripada Sintesis-Otak Kanan-Sosial-SMPNONPBTIK } \\
\text { Analisis-Otak-Kiri-Sosial-SMPPBTIK lebih tinggi daripada } \\
\text { Sintesis-Otak-Kanan-Sosial-SMPPBTIK } \\
\text { Analisis-Otak Kiri-eksak-SMPNONPBTIK lebih tinggi } \\
\text { daripada Sintesis-Otak-Kanan-Eksak-SMPNONPBTIK } \\
\text { Analisis-Otak Kiri-Eksak-SMPPBTIK lebih tinggi daripada } \\
\text { Sintesis-Otak Kanan-EksakSMPPBTIK. }\end{array}$ \\
\hline $\begin{array}{l}\text { Analisis Otak Kiri-Sosial-SMANONPBTIK lebih kecil } \\
\text { daripada Analisis-Otak-Kiri-Sosial-SMAPBTIK } \\
\text { Analisis-Otak Kiri-eksak-SMANONPBTIK lebih kecil } \\
\text { daripada Analisis Otak-Kiri-Eksak-SMAPBTIK } \\
\text { Sintesis-Otak Kanan-Sosial-SMANONPBTIK lebih kecil } \\
\text { lebih kecil daripada Sintesis-Otak-Kanan-Sosial- } \\
\text { SMAPBTIK }\end{array}$ \\
\hline SMA
\end{tabular}




\begin{tabular}{|c|c|c|}
\hline No & $\begin{array}{c}\text { Jenjang } \\
\text { Pend. }\end{array}$ & Hasil Penelitian \\
\hline & & $\begin{array}{l}\text { Sintesis-Otak-Kanan-Eksak-SMANONPBTIK lebih kecil } \\
\text { daripada Sintesis-Otak Kanan-EksakSMAPBTIK } \\
\text { Analisis Otak-Kiri-Eksak-SMAPBTIK lebih kecil daripada } \\
\text { Analisis-Otak-Kiri-Sosial-SMAPBTIK } \\
\text { Sintesis-Otak Kanan-EksakSMA PBTIK lebih kecil daripada } \\
\text { Sintesis-Otak-Kanan-Sosial-SMA PBTIK } \\
\text { Analisis Otak Kiri-Sosial-SMANONPBTIKlebih besar } \\
\text { daripada Sintesis-Otak Kanan-Sosial-SMANONPBTIK } \\
\text { Analisis-Otak-Kiri-Sosial-SMAPBTIK lebih besar daripada } \\
\text { Sintesis-Otak-Kanan-Sosial-SMAPBTIK } \\
\text { Analisis-Otak Kiri-eksak-SMANONPBTIK lebih kecil } \\
\text { daripada Sintesis-Otak-Kanan-Eksak-SMANONPBTIK } \\
\text { Analisis Otak-Kiri-Eksak-SMAPBTIK lebih kecil daripada } \\
\text { Sintesis-Otak Kanan-EksakSMAPBTIK. } \\
\text { Analisis Otak Kiri-Sosial-SMPNONPBTIK lebih rendah } \\
\text { daripada Analisis-Otak-Kiri-Sosial-SMPPBTIK } \\
\text { Analisis-Otak Kiri-eksak-PTNONPBTIK lebih rendah dari } \\
\text { Analisis Otak-Kiri-Eksak-PTPBTIK } \\
\text { Sintesis-Otak Kanan-Sosial-PTNONPBTIK lebih rendah } \\
\text { dari Sintesis-Otak-Kanan-Sosial-PTPBTIK } \\
\text { Sintesis-Otak-Kanan-Eksak-PTNONPBTIK lebih rendah } \\
\text { dari Sintesis-Otak Kanan-EksakPTPBTIK }\end{array}$ \\
\hline 4. & PT & $\begin{array}{l}\text { Analisis Otak-Kiri-Eksak-PTPBTIK lebih rendah dari } \\
\text { Analisis-Otak-Kiri-Sosial-PTPBTIK } \\
\text { Sintesis-Otak Kanan-EksakPTPBTIK lebih rendah dari } \\
\text { Sintesis-Otak-Kanan-Sosial-PTPBTIK } \\
\text { Analisis Otak Kiri-Sosial-PTNONPBTIK lembih tinggi } \\
\text { Sintesis-Otak Kanan-Sosial-PTNONPBTIK } \\
\text { Analisis Otak-Kiri-Eksak-PTPBTIK hampir sama dengan } \\
\text { Sintesis-Otak Kanan-EksakPTPBTIK. }\end{array}$ \\
\hline
\end{tabular}


b. Pengaruh pengemasan informasi PBTIK terhadap akselerasi pembelajaran bidang sosial dan eksakta yang dikontrol biologi komunikasi

Pengujian terhadap pengaruh pengemasan informasi pembelajaran berbasis TIK juga dilakukan analisisnya pada kelompok sosial dan eksakta, yang keduanya dikontrol oleh biologi komunikasi yang dialami peserta didik ketika mengikuti pembelajaran. Berikut adalah diagram jalur dari masing-masing pengujian pengaruh serta rangkuman tabel hasil pengujian pengaruh pengemasan pada kelompok sosial dan eksak.

Tabel 2

\begin{tabular}{|c|c|c|c|l|}
\hline Hipotesis & $\mathrm{t}_{\mathrm{i}}$ & $\begin{array}{c}\mathrm{t}_{\text {tabel; }} \\
(\alpha)=0.05\end{array}$ & $\mathrm{df}$ & Keputusan \\
\hline $\mathrm{H}_{0}: P_{\mathrm{ZX} 1}=0$ & & & & \\
$\mathrm{H}_{1}: P_{\mathrm{ZX} 1} \leqslant 0$ & 5,262482608 & 1.6645 & 118 & Tolak $\mathrm{H}_{0}$ \\
\hline $\mathrm{H}_{0}: P_{Z Y}=0$ & & & & \\
$\mathrm{H}_{1}: P_{Z Y} \leqslant 0$ & 8,511442782 & 1.6645 & 118 & Tolak $\mathrm{H}_{0}$ \\
\hline
\end{tabular}

\section{Tabel 4.3}

\begin{tabular}{|c|c|c|c|l|}
\hline Hipotesis & $\mathrm{t}$ & $\begin{array}{c}\mathrm{t}_{\text {tabel; }} \\
(\alpha)=0.05\end{array}$ & $\mathrm{df}$ & Keputusan \\
\hline $\mathrm{H}_{0}: P_{\mathrm{ZX} 2}=0$ & & & & \\
$\mathrm{H}_{1}: P_{\mathrm{ZX} 2} \leqslant 0$ & 18,89357963 & 1.6645 & 118 & Tolak $\mathrm{H}_{0}$ \\
\hline $\mathrm{H}_{0}: P_{Z Y}=0$ & & & & \\
$\mathrm{H}_{1}: P_{Z Y} \leqslant 0$ & 23,03821727 & 1.6645 & 118 & Tolak $\mathrm{H}_{0}$ \\
\hline
\end{tabular}

\section{Proses perilaku biologi komunikasi yang terjadi pada otak} peserta didik

Proses perilaku biologi komunikasi yang terjadi ketika peserta didik jenjang SD-PT melakukan aktivitas belajar mengamati, merasa, memahami dan kecenderungan bertindak terjadi pada bagian-bagian spesifik belahan otak kiri dan kanan, yaitu 
Frefrontal (Fp); Frontal (F); temporal (T); Parietal (P); Central (C); Occivital (O) ; dan Parasagital (FCP), dengan kecepatan gelombang Alpha dan Betha yang berbeda dalam menerima, mengolah dan mentransformasikan pesan baik pesan pembelajaran kelompok sosial maupun eksakta sebelum atau selama mengikuti pembelajaran berbasis teknologi informasi dan komunikasi.

a. Aktivitas Perilaku biologi komunikasi ketika melihat

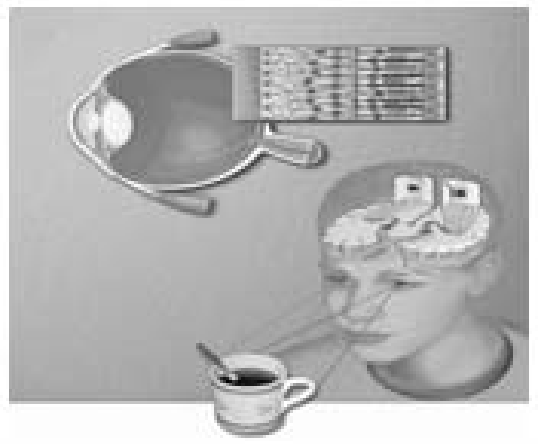

Gb. a. Bagaimana Occipitl menerima stimulus dari indera visual

b. Aktivitas Perilaku biologi komunikasi ketika merasa

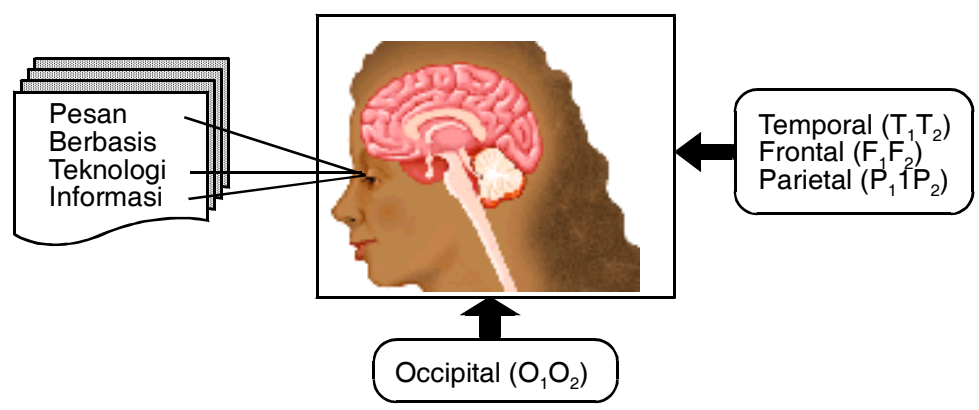

Gb. b. Perspektif Biologi Komunikasi melalui aktivitas "merasa" (Sumber: Hasil Riset, 2004) 
c. Aktivitas Perilaku biologi komunikasi ketika merasa

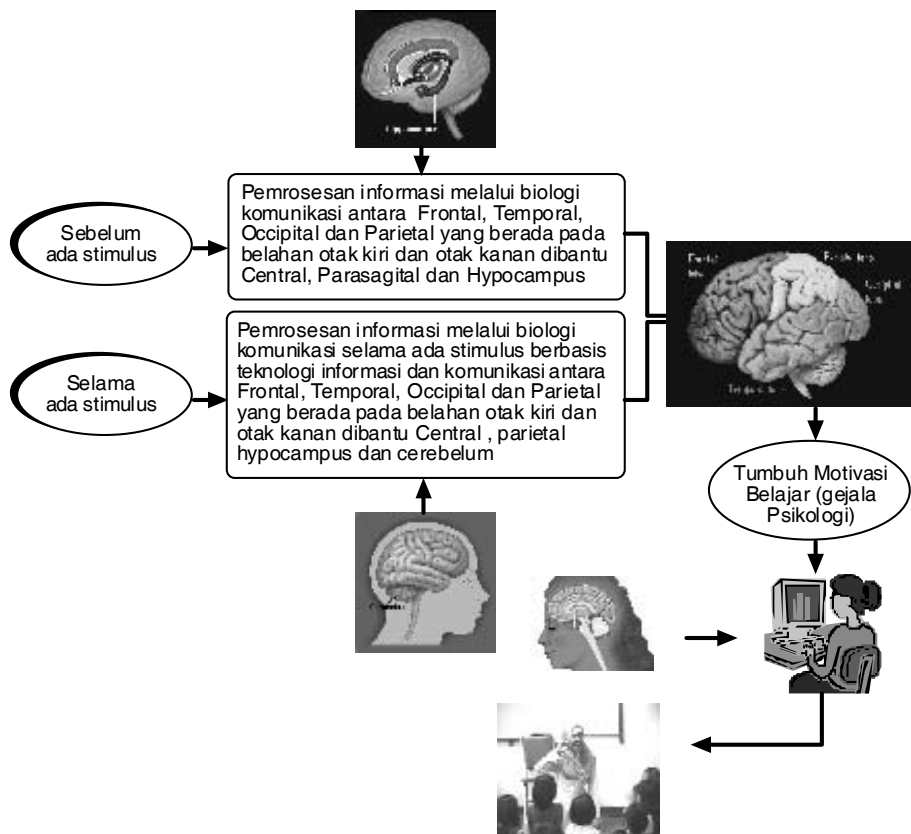

Gb. 4.5 Model pemrosesan Informasi yang melibatkan proses biologi komunikasi, psikologi komunikasi berdasarkan ada atau tidak adanya stimulus berbasis teknologi informasi dan komunikasi dalam bentuk aktivitas "memahami"

(Sumber : Hasil Riset, 2004)

d. Aktivitas Perilaku biologi komunikasi ketika melakukan kecenderungan bertindak

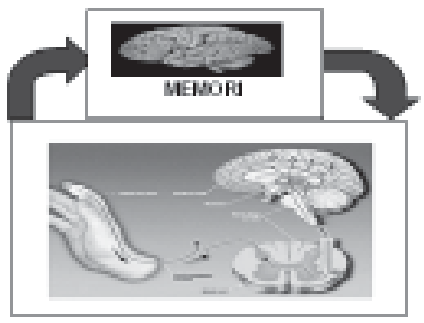

Gb. 4.6 Proses terjadinya kecenderungan bertindak sebagai salah satu perspektif biologi komunikasi. 
3. Telaah perspektif bidang keilmuan terhadap fenomena perilaku biologi komunikasi otak pada peserta didik

a. Ilmu komunikasi:

Memberikan kontribusi pemikiran pada aspek kajian bagian sepesifik otak sebagai komponen-komponen terjadinya komunikasi secara biologi, yang merujuk kepada penjelasan komunikasi secara intrapersonal pada indivdu

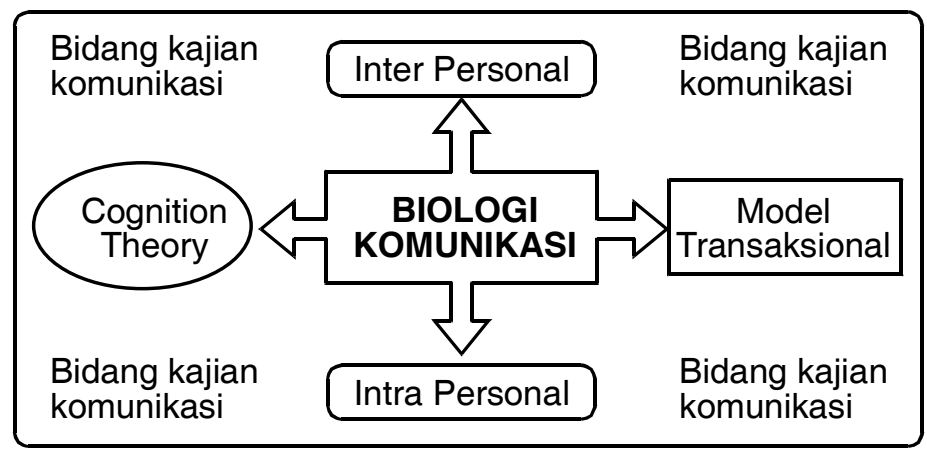

Gb. 4.11.Perspektif IImu Komunikasi terhadap Biologi Komunikasi otak kiri dan otak kanan (Hasil Riset, 2004)

b. Psikologi:

Memberikan kontribusi pemikiran pada aspek pemrosesan informasi yang terjadi pada otak kiri dan otak kanan yang berkaitan dengan komunikasi nonverbal khususnya dalam proses pengkodean pesan yang terjadi selama metabolisme terjadi dalam otak. Khususnya dalam penjelasan mengenai proses dan keterhubungan antara Short Term Memory dan Long Term Memory ketika peserta didik melakukan aktivitas belajar, sebagaimana dapat dilihat pada bagan berikut. 


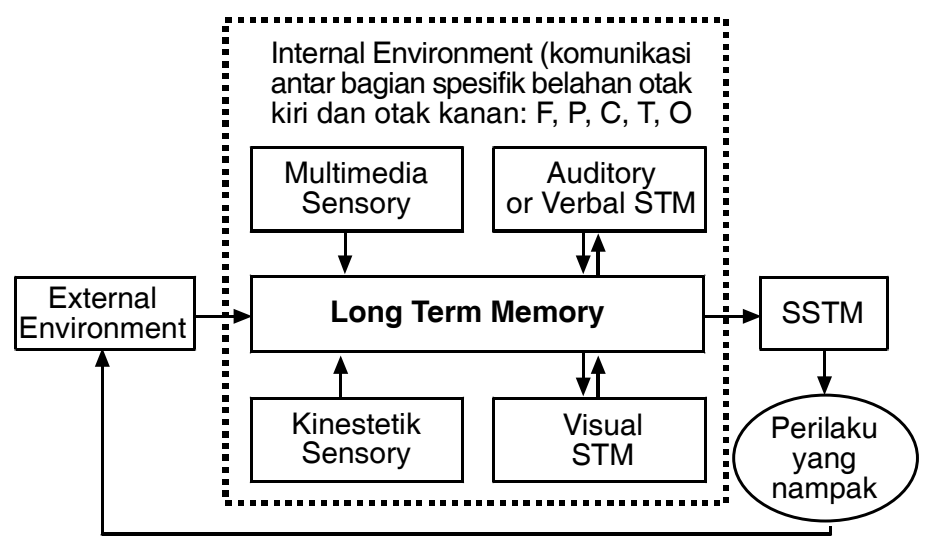

Gb. 4.12 Model Pemrosesan informasi hasil telaah biologi komunikasi dari perspektif psikologi yang melibatkan

LTM dan STM (Hasil Penelitian, 2004)

c. Kedokteran:

Memberikan penjelasan dari sudut sistem syaraf dan komunikasi antarsel syaraf otak, dan penjelasan terjadinya prilaku biologi komunikasi berdasarkan bagian spesifik otak seperti Fr, F, P, T, Occ, C, dan Prc, serta penjelasan mengenai jalur-jalur proses komunikasi secara biologi berlangsung berdasarkan jenis stimulus yang diterima. Disamping itu juga memberikan penjelasan fungsi belahan otak kiri dan kanan yang akan memperngaruhi memorikreativitas-learning, khususnya yang berkaitan dengan pemecahan masalah.

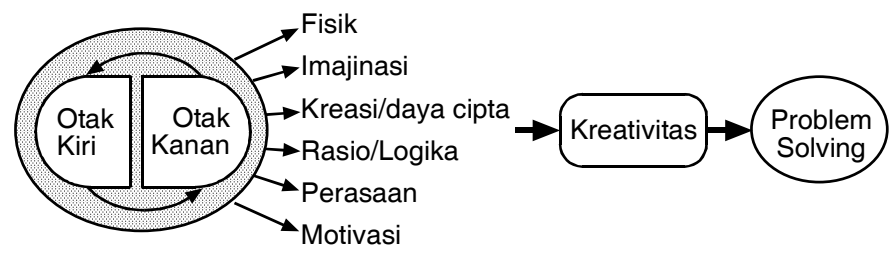

Gb. 4.13

Pembentukan kreativitas dalam pemecahan masalaah 
d. Ilmu Pendidikan

Memberikan penjelasan dari kajian tentang:

(1) Alur informasi berdasarkan stimulus dari media pembelajaran khususnya visual, audio dan AV terhadap fenomena kerja otak atau interaksi otak kanan dan otak kiri dan kontrol perbedaan kemampuan berdasarkan usia atau jenjang pendidikan.

(2) Pemrosesan informasi dalam kaitannya dengan psikologi kognitif khususnya berkaitan dengan memory jangka panjangd an jangka pendek.

(3) Kajian tentang fisiologi otak

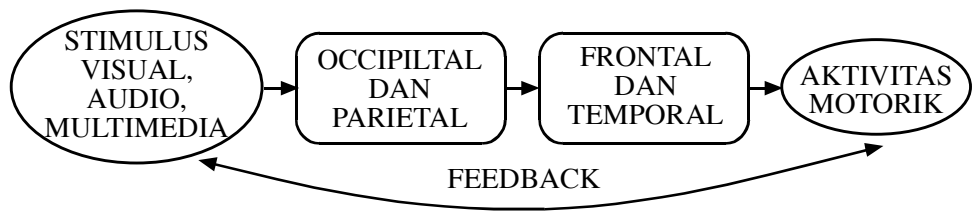

Gb. 4.14 Pola Interaktif dalam pembelajaran CBI berdasarkan Biologi Komunikasi

Dalam telaah secara sistem bagaimana biologi komunikasi otak kiri dan otak kanan ini menjadi landasan dalam menganalisis dan mendesain sistrem pembelajaran yang melibatkan pengajaran, kurikulum, penilaian dan lingkungan berlajar. Semua komponen tersebut harus berdasarkan kemampuan kerja otak peserta didik. 


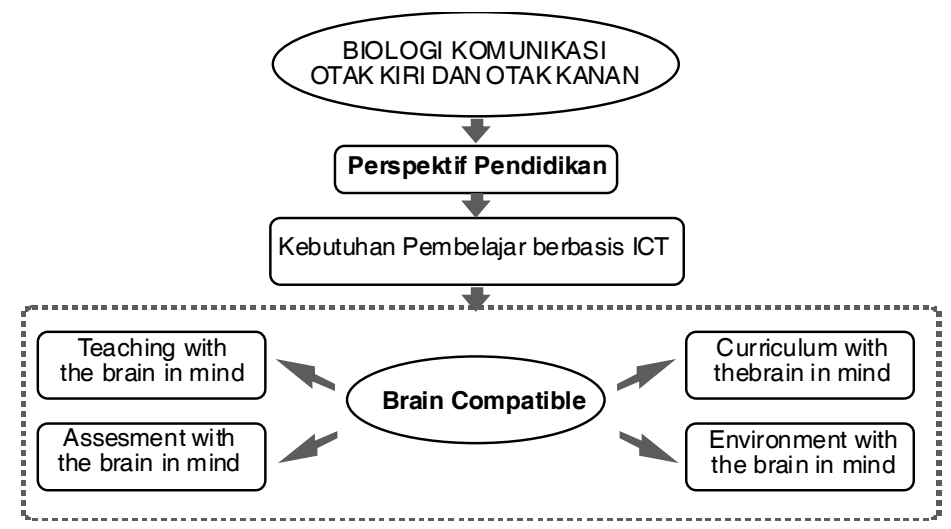

Gb. 4.15 Biologi Komunikasi dalam Implementasi Belajar berbasis Otak melalui Perspektif Teknologi Informasi

(Hasil Riset, 2004)

e. Teknologi Informasi

Memberikan penjelasan terhadap proses belajar yang terjadi pada otak pada dasarnya telah ditransfer atau ditiru oleh sistem kerja komputer. Maka prilaku biologi komunikasi merupakan dasar dari sistem pembelajaran berbasis teknologi informasi dan komunikasi dan sebaliknya prilaku tersebut akan lebih cepat berlangsung melalui stimulusstimulus yang diprogram melalui komputer dan sistem jaringan seperti intranet, internet, dan dukungan manajaemen ICT.

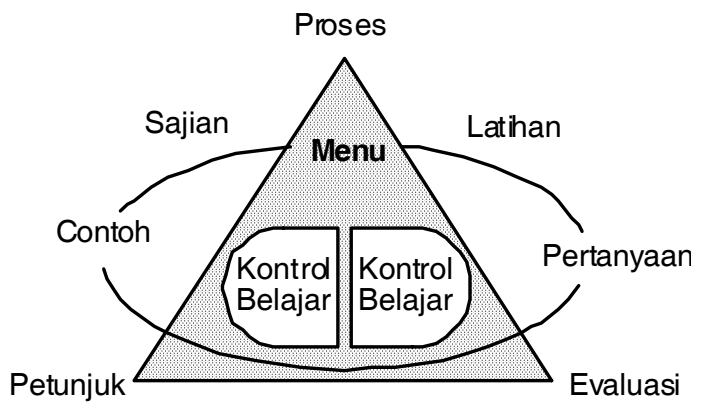

Gb. 4.16 Komponen-komponen dalam Hypertutorial sebagai salah satu perspektif TI dalam Biologi Komunikasi 
f. Ilmu Budaya

Memberikan penjelasan terhadap peran guru dalam membudayakan:

(1) Inovasi dalam desain laboratorium nyata yang mampu membelajarkan peserta didik baik kemampuan otak kiri maupun otak kanan

(2) Inovasi dalam menemukan model-model pembelajaran yang mampu mengoptimalkan kemampuan belahan otak.

4. Model pembelajaran berbasis teknologi informasi dan komunikasi yang mampu memberikan optimalisasi proses perilaku biologi komunikasi otak

a. Jenjang SD, Kajian model ini lebih ditujukan kepada aspek:

(1) Optimalisasi kreativitas, teligensi, fisik, emosi, minat dan kondisi dalam diri peserta didik melalui desain model yang memperhatikan sajian informasi secara visual, audio atau motorik .

(2) Model pembelajaran yang betul-betul didesain dengan memperhatikan teori belajar adaptif, modalitas, dan kognitif fleksibilitas dalam bentuk latihan dan Tutorial.

b. Jenjang SMP, Kajian model lebih ditujukan kepada:

(1) Optimalisasi berpikir lateral, fleksibilitas kognitif

(2) Model gabungan antara tutorial, simulasi, dan latihan siswa mampu dengan cepat menyelesaikan pelajaran .

c. Jenjang SMA, Kajian model lebih ditujukan kepada:

(1) Mengoptimalkan penglihatan, pendengaran, dan kinestetik yang ditujukan kepada pemecahan masalah.

(2) Menggabungkan kemampuan berpikir logik dan kreativitas mengembangkan pikiran-pikiran yang sifatnya discovery dan inquiry yang membantu peserta didik mencapai kecepatan dan kreativitas belajar yang lebih mandiri.

(3) Bentuk multi media interaktif yang menyajikan informasi belajar dalam bentuk pola gabungan yaitu yang berisi petunjuk, tes-tes kemampuan awal berupa latihan, 
latihan , serta alur penyajian materi secara bercabang dan bahkan diketengahkan ilustrasi dalam bentuk video dan simulasi animasi teks dan gambar akan lebih mampu memberikan proses belajar secara utuh.

d. Jenjang PT, Kajian model lebih ditujukan pada:

(1) Penerapan Mapping concept, Problem Based Learning

(2) Kemampuan logika yang sifatnya advance organizer of knowledge,

(3) Pengembangan inquiry \& Dicovery

(4) Model disajikan dengan dukungan e-learning, dan ICT.

\section{Biologi komunikasi sebagai Landasan Praktis dalam desain Model Pembelajaran}

Sebagaimana ditegaskan pada beberapa hasil penelitian dan pembahasan, maka model biologi komunikasi ini adalah cabang ilmu komunikasi yang mempelajari gejala-gejala perilaku biologi komunikasi yang mempengaruhi perilaku psikologis yang nampak pada diri individu. Khususnya dalam konteks pembelajaran bahwa model biologi komunikasi ini dapat dijadikan pisau analisis dalam menjelaskan aktivitas belajar peserta didik ketika mengamati, merasa, memahami, dan kecenderungan bertindak berdasarkan ada atau tidak adanya stimulus pembelajaran berbasis teknologi komunikasi dan informasi. Analisis perilaku komunikasi baik dari sudut bioogi komunikasi maupun psikologi komunikasi ini mampu menjelaskan komunikasi intra dan interepersonal. Sebagai salah satu syarat sebuah cabang ilmu komunikasi, maka secara akademik biologi komunikasi ini telah memenuhi persyaratan, yaitu : a) memiliki komponen-komponennya, yaitu berupa bagianbagian spesifik otak yang mencakup prefrontal, frontal, temporal, parietal, central, occipital dan parasagital; b) menunjukkan dan menjelaskan proses interaksi yang dilakukan komponenkomponennya; c) menunjukkan proses traksaksi yang terjadi antar komponen-komponennya; dan d) memiliki kajian dari 
perspektif keilmuan yang terkait dengan aspek uji validasi secara teori maupun praktek.

Berikut adalah visualisasi dari model biologi komunikasi, yaitu:

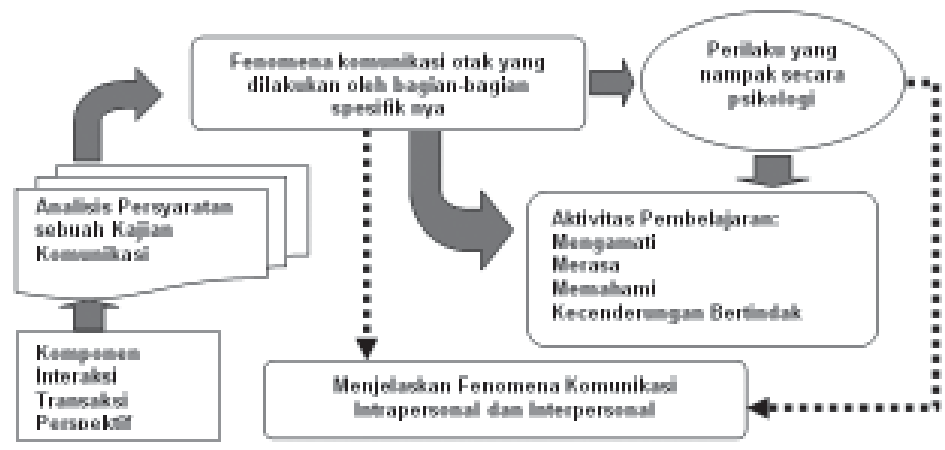

Gb. 4.66 Model Biologi Komunikasi

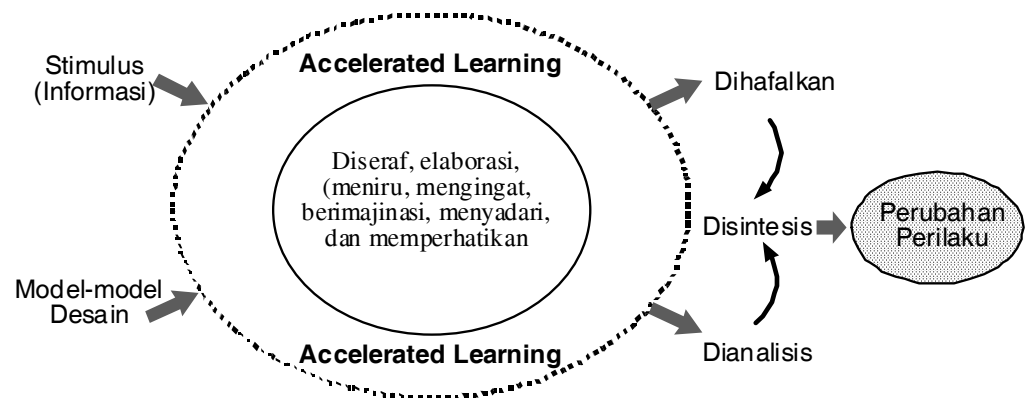

Gb. 4.19 Model jalur pengolahan informasi dalam otak Menuju proses akselerasi 


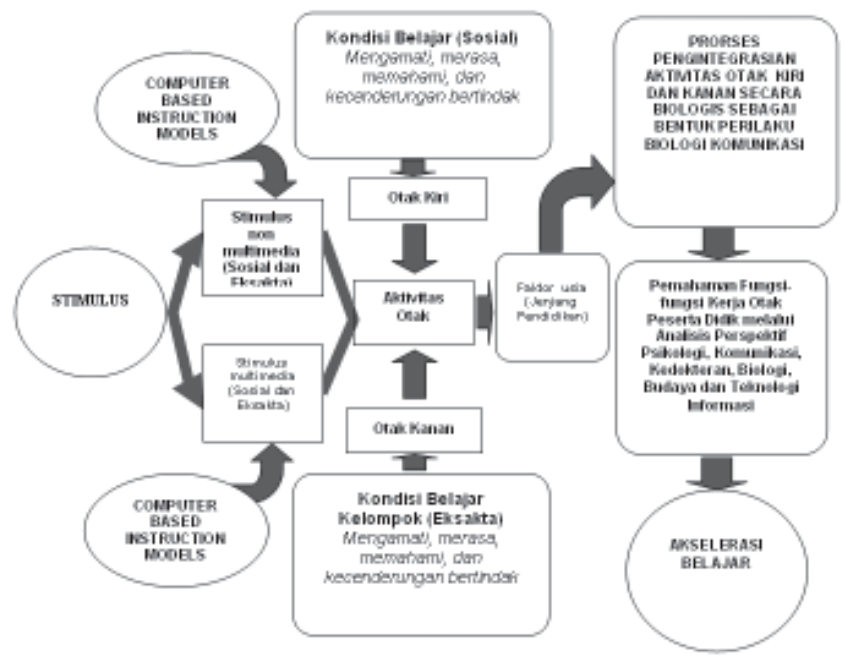

Gb. 4.10 Model Pemikiran Biologi Komunikasi Otak Kiri Dan Otak Kanan Berbasis Teknologi Informasi Pada Jenjang Pendidikan Dasar sampai dengan Pendidikan Tinggi

\section{a. Model Pembelajran Jenjang SD berdasarkan Biologi Komunikasi}

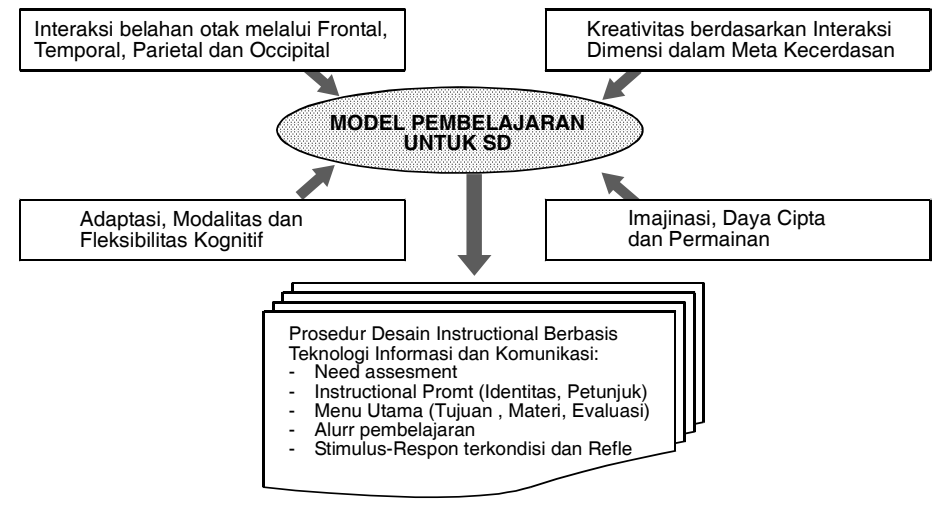

Gb. 4.55 Model Pembelajaran Jenjang Sekolah Dasar dengan Pembelajaran Berbasis Teknologi Informasi dan Komunikasi Melalui Pemberdayaan Otak Peserta Didik (Hasil Riset, 2005) 
Dengan demikian bahwa dengan memperhatikan tingkat perkembangan siswa baik pada aspek inteligensi, fisik, emosi, minat dan kondisi dalam diri peserta didiK itu sendiri maka bagian temporal, frontal, parietal akan dibantu oleh occipital. Hasilnya dalam bentuk pembelajaran yang lengkap dan dialami oleh siswa jenjang Sekolah Dasar bukan hanya pada tataran belahan otak saja juga diharapkan mampu menembus perasaan dengan demikian selanjutnya akan senang jika diajak belajar. Terlebih jika model pembelajaran ini didesain melalui komputer multimedia. Dalam hal ini dikemukakan Solehah (2004) yang mengajar di kelas V terbukti bahwa model pembelajaran yang berbasis teknologi informasi komputer yang mampu membantu anak dalam memahami materi secara utuh baik itu konsep, bentuk, dan proses adalah model penyajian yang mengandung unsur permainan dengan dilengkapi tutorial atau petunjuk bagi siswa bagaimana ia menyelesaikan permainan. Setelah selesai belajar maka berpikir kreatif pada peserta didik ini bisa terwujud, di mana menurut Stenberg dalam Collin \& Rose (1997: 211), bahwa terdapat 3 (tiga) tahap dalam berpikir kreatif yaitu: insight, combination, compare old and new.Dalam kegiatan belajar seperti dijelaskan di atas maka kemampuan otak kiri yang berisi kemampuan pemahaman dan pengetahuan tentang informasi yang dilihat dan diingatnya saat melihat gambar yang disajikan, dibantu oleh kemampuan otak kanan yang berisi kreativitas dan imajinasi dalam memperhitungkan perbandingan antara bahan-bahan bangunan yang diperlukan, sehingga akhirnya siswa bisa mengambil kesimpulan untuk memilih jawaban yang benar. Dengan ditemukannya jawaban yang benar maka peserta didik akan merasa bahwa proses belajar yang ia lakukan cukup memberikan makna. Dengan perolehan makna inilah maka langkah berikutnya walaupun didesain cukup komplek, akan tetapi npeserta didik akan termotivasi untuk bisa melaluinya dengan mulus sehingga evaluasi yang akan ia hadapi berikutnya akan lebih baik dari hasil sebelumnya. 
Berikut adalah ilustrasi pemikiran tentang model pembelajaran berdasarkan teknologi informasi dan komunikasi yang berusaha membangkitkan aktivitas belahan otak kiri dan kanan yang diharapkan mampu membantu akselerasi belajar peserta didik.

Jika dikaitkan dengan adanya kelompok mata pelajaran eksak dan sosial, maka desain pembelajaran berbasis teknologi informasi dan komunikasi ini pada dasarnya sama dalam arti mengikuti prosedur dan latar belakang desain yang sama, walaupun dari temuan penelitian ini menunjukkan bahwa model-model pembelajaran untuk kelompok eksak ternyata memiliki pengaruh yang lebih tinggi dari pada kelompok sosial terhadap akselerasi pembelajaran yang dikontrol oleh biologi komunikasi otak kanan dan otak kiri. Berdasarkan deskripsi dan pembahasan di atas maka model pembelajaran yang bisa diadopsikan dalam pembelajaran berbasis teknologi informasi dan komunikasi yang dikontrol oleh biologi komunikasi pada jenjang sekolah dasar ini belum mengarah kepada penekanan secara mendalam dari aspek keluasan, dan kekomplekan materi yang disajikan dan yang dijadikan pokok pemikirannya adalah aspek adaptasi dan menyenangkan.

b. Model Pembelajaran Jenjang SMP berdasarkan Biologi Komunikasi

Berdasarkan deskripsi hasil data sebelumnya diperoleh informasi bahwa perkembangan belajar dan kecepatan belajar siswa selama pembelajaran berlangsung terutama dengan menggunakan model LCBT (Lateral Computer Based Tutorial), sangat tergantung kepada bagaimana guru mengemas materi tersebut. Darmawan, dkk (2003: 89) menjelaskan bahwa:

LCBT sangat penting membantu kecepatan dan melatih berpikir kritis siswa dan dapat memberikan pengalaman 
berpikir kritis pada guru dalam pengembangan stimulusstimulus pembelajaran yang mampu merangsang siswa berpikir cepat, tepat dan bermakna selama pembelajaran.

Model pembelajaran Lateral Computer Base Tutorial, ini pada dasarnya menerapkan prinsip model latihan dan tutorial dengan melalui penerapan berpikir lateral atau loncatan berpikir yang didukung kemampuan visual dalam memahami informasi pembelajaran dari layar komputer. Semua komponen desain sajian pembelajaran berbasis teknologi informasi dan komunikasi ini mesti memperhatikan bagaimana warna dipilih, bagaimana animasi diatur dari segi timer , bagaimana audio sesuai dengan gambar objek atau animasi yang diilustrasikan. Semuanya ini jika dipadukan dalam bentuk tutorial yang berbasiskan LCBT maka peserta didik akan lebih cepat lagi belajarnya terlebih hal ini cukup memberikan ketenangan belajar dan tumbuh perasaan tentang dan percaya diri. Terlebih jika model didesain dengan menambahkan pencitraan terhadap latar belakang musik yang mampu menyentuh sensory otak pada belahan kanan maka proses berpikir akan terjadi secara seimbang, dikontrol oleh alunan musik yang membuat individu stabil dalam jalur pikirnya serta merasa tenang. Dalam hal bacground musik ini penulis adaptasi dari Bonny (Stephen Merrit, 2003: 28) bahwa" MPH (Memandu Pencitraan Musik) mampu mengajak pendengar untuk menuliskan, menggambarkan, dan menceritakan kembali apa yang dipelajarinya." Terlebih jika petunjuk (totorial line) yang dikembangkan cukup jelas mengajak peserta didik belajar sampai dengan tuntas. Desain model tutorial dewasa ini penulis sarankan untuk memperhatikan aspek latar belakang (sound effect) musik yang disesuikan dengan kelompok mata pelajaran. Karena musik bisa memberikan ciri dan gaya belajar dan berpikir sesuai dengan pribadi masing-masing. Lazanov dalam Merrit (2003: 50) menjaslakn bahwa "Dampak terapi musik apabila dikaitkan dengan seni, drama, dan konsentrasi dalam 
suasana santai, mampu mengaktifkan kapasitas "paraconscious" yaitu semua tingkat kejiwaaan yang tidak sadar yang tidak terbatas. Metode inilah yang disebut metode Accelerated Learning".

Demikian juga petunjuk terebut lebih cenderung banyak disajikan dalam bentuk audio (narator), maka sentuhan audio ini juga harus betul-betul mampu mengoptimalkan bagian spesifik lobus Temporal baik sebelah kiri maupun sebelah kanan. Colling \& Rose (1997: 183) mengemukakan bahwa" Music is the highest part of human culture and expression. It allows us to feel connected to something greater. Underheath music is a code of rythm and sounds that your left brain relates to while the right brain relates to the texture of the sounds." Demikian juga menurut Rakhmat, (2004:12) bahwa lobus temporal berkaitan dengan memori, emosi, pendengaran dan bahasa. Adapun visual ditujukan pada optimalisasi bagian spesifik occipital dimana prinsip kerjanya selalu bersilangan antara mata kiri dengan belahan otak kanan dan mata kanan dengan belahan otak kiri. Kondisi ini memberikan makna bahwa belajar memang tidak bisa hanya otak kiri atau otak kanan saja melainkan harus kedua-duanya melakukan aktivitas sehingga apa yang disebut akselerasi belajar dapat berlangsung secara komplek. Dalam desain model pembelajaran berbasis teknologi informasi dan komunikasi untuk jenjang SMP berdasarkan tiga dimensi di atas juga harus direlevansikan dengan dimensi berpikir berdasarkan indera visual, audio dan kinestetik yang dimiliki oleh model tutorial. Berdasarkan hasil temuan dalam penelitian ini penulis adaptasikan dengan apa yang dikemukakan oleh Eric (2000:186) mengenai "Eye Movement and Thinking" , mengemukakan bahwa " there are seven basic eye movements that related to thinking." Pendapat tersebut menunjukkan bahwa pada dasarnya berpikir akan berhubungan dengan aktivitas kognitif. Hasil tes laboratoriumnya menunjukkan bahwa : "Cognitive activity 
occuring in one hemisphere triggers eye movements in the opposite hemisphere". Lebih lanjut dijelaskan bahwa ketujuh gerakan visual dasar yang berhubungan dengan berpikir ini adalah sebagai berikut:

1) Visual thinking of stored picture memories;

2) Visual thinking of created new pictures;

3) Auditory thingking and recalling souns;

4) Auditory thinking and creating new sounds;

5) Internal dialogue (talking to your self);

6) Experiencig feelings;

7) Authomatic resposes.

Berdasarkan tujuh dasar gerakan visual mata di atas terlihat bahwa kaitan antara dimensi visual, audio dan kinestetik diasumsikan mampu mendukung proses berpikir yang lebih menekankan pada proses kognitif secara fleksibel. Prinsip berpikir fleksibel inilah yang seharusnya diperhatikan dalam mendesain model pembelajaran dalam bentuk tutorial berbasis teknologi informasi dan komunikasi. Karena dengan sentuhan teknologi seperti dalam mengkondisikan dan mengatur gerakan berdasarkan kecerdasan visual dan audio maka akan berpengaruh terhadap keberhasilan siswa dalam menyelesaikan pembelajaran (mastery learning) tanpa hambatan. Jika informasi pembelajaran yang dikemas berupa tulisan, image atau objek bahkan ada animasi dan suara (multimedia) maka dimensi berpikir dan dimensi biologi komunikasi, psikologi dan proses belajar menjadi tolak ukur kualitas aktivitas proses belajar menunjuk kecepatan belajar (accelerated learning), dalam hal ini Jensen (2000:187) lebih lanjut menjelaskan bahwa strategi yang baik dalam menerapkan pergerakan visual yang dikaitkan dengan otak dapat didesain secara terintegrasi dalam model Tutorial, dapat diilustrasikan sebagai berikut :

a) Acces Feeling With Regard To The Word: Start with eyes looking down. 
b) Visualize the image of the word: Move eyes up and to the right.

c) Segment a word in auditory memory: Say the letter while looking to the night;

d) Cement a word kinesthetically : Trace the letter of it with your finger.

e) Recall a stored image of the word: Colse eyes and look to the left;

f) Write out the correct spelling on paper;

g) To segment the succes: Look down to the right and feeling of empowerment.

Jika melihat uraian di atas ternyata dalam proses pembelajaran melalui 7 aktivitas ini aspek visual, audio, dan kinestetik berlangsung secara terintegrasi dan tentunya dikontrol atau ditentukan oleh aktivitas belahan otak kiri maupun kanan sesuai dengan jenis aktivitasnya. Dari ketujuh langkah di atas cukup memberikan dasar bagaimana peserta didik yang sudah berada pada tingkat kemampuan berpikir abstract yaitu pada rentang 10-20 thn (Jensen, 2000:179). Ketiga kecerdasan yaitu visual, audio dan kinestetik ini merupakan kunci dalam keberhasilan accelerated learning dalam satu pembelajaran sebagaimana dikemukakan oleh Colling \& Rose 1997: 171) melalui pernyataan yaitu: Yous saw it, heard it, read it, did it, and said it. Dalam kaitannya dengan alur peserta didik mengikuti pembelajaran dengan tutorial ini, maka salah satu yang dapat dikembangkan dalam desain modelnya adalah dengan menggunakan konsep Mind Mapping (Buzan, 1997:83). Di mana dengan konsep ini fungsi kerja dari semua bagian spesifik otak akan bisa diberdayakan semua dan tertuju kepada satu tujuan (keberhasilan belajar) melalui proses cepat dnegan pemberdayaan fungsi-fungsi bagian spesifik atak. Melalui prinsip Mind Mapping ini maka jalur bercabang (branching) yang dikembangkan dalam desain model tutorial dapat diikuti dan cepat dilalui oleh peserta didik karena hal 
ini sangat berkaitan dengan tuntutan kerja semua proses berpikir. Dijelaskan lebih lanjut menurut Buzan (1997: 59) bahwa :

The map is an expression of Radiant Thinking and is therefore a natural function of human mind. The mind map can be applied to every aspect of life where improved learning and clearer thinking will enhance human performance. The Mind Map has four essential characteritics :

a) The subject of attention is crystallised in a central image;

b) The main themes of the subject radiant from the central image as branches.

c) Branshes comprise a key image or key word printed on an associated line. Topics of lesser importance are also represented as branches attached to higher level branches.

d) The branches form a connected nodal structure.

Dalam hal ini Buzan (1997:60) menegaskan bahwa:" Mind map may be enhance and enrich with colour, pictures, codes and dimension to add interest, beauty and individuality. These in turn aid creativity, memory and specifically the recall of information." Terutama sekali untuk model yang betul-betul menerapkan konsep ICT (Informatioan Communication \&Technology) yang mendasar, yaitu yang mampu memberikan kesempatan pada siswa untuk memilih alternatif jalur penuntasan dalam mempelajari materi yang diajarkan. Misalnya dalam pelajaran Teknologi Informasi dan Komunikasi pada pokok bahasan belajar Microsoft Word, ternyata dengan model tutorial ini siswa lebih tenang dan cepat dalam menanggapi semua materi yang disajikan. Melalui tutorial ini juga siswa cenderung lebih mampu mengontrol kemampuan dalam menjawab soal-soal yang disajikan. Temuan dalam penelitian ini menunjukkan bahwa sebetulnya indera-indera yang diperlukan dalam belajar hendaknya mampu dikembangkan secara terintegrasi dalam sebuah proses pembelajaran. Gardner dalam Stine (2003: 42) bahwa 
indera belajar mencakup : verbal, logika, visual, musikal, kinestetik, hubungan intrapersonal, dan hubungan interpersonal.

Selain melalui model tutorial model pembelajaran berbasis teknologi informasi untuk jenjang SMP ini diantaranya adalah model simulasi yang digabungkan atau terintegrasi dalam model tutorial. Model ini dikatakan oleh Aris (2004) yang mengajar Fisika, di mana ketika siswa mengikuti pembelajaran dengan model gabungan antara tutorial, simulasi, dan latihan siswa mampu dengan cepat menyelesaikan pelajaran. Semua model berpikir yang dituntut sangat memungkinkan bisa dilakukan oleh peserta didik berdasarkan kemampuan bagian spesifik otaknya, sebagaimana dijelaskan oleh Stine, (2003:212) bahwa Model berpikir meningkatkan enam kali lipat kekuatan otak, dengan cara memikirkan situasi dari setiap sudut pandang berikut yaitu : berpikir obyektif; berpikir kritis; berpikir positif; Berpikir kreatif; berpikir intuitif; berpikir tentang model. Temuan ini memberikan penjelasan terhadap pencapaian kecepatan waktu pembelajaran. Berikut adalah visualisasi model pemikiran tentang model pembelajaran berbasis teknologi informasi dan komunikasi berdasarkan biologi komunikasi. 


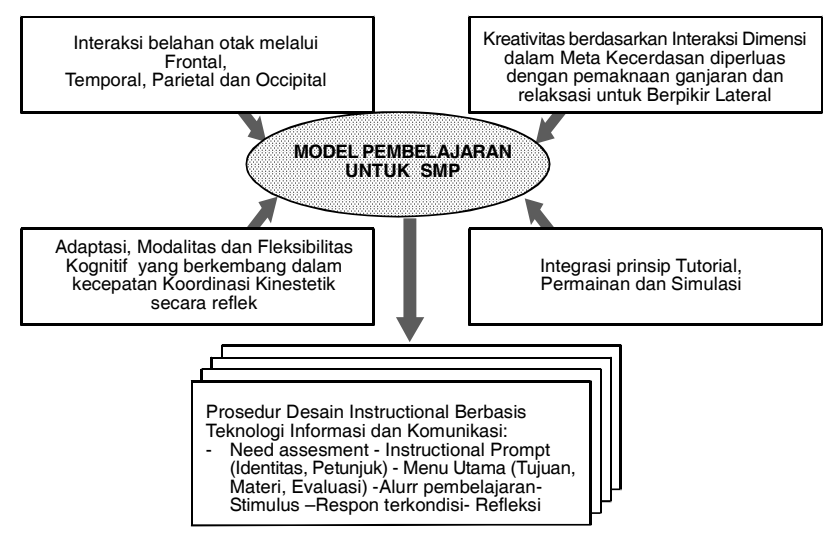

Gb. 4.56 Model Pembelajaran Jenjang Sekolah Menengah Pertama dengan Pembelajaran Berbasis Teknologi Informasi dan Komunikasi Melalui Pemberdayaan Otak Peserta Didik

(Hasil Riset, 2005)

c. Model Pembelajaran Jenjang SMA berdasarkan Biologi Komunikasi

Model pembelajaran berbasis teknologi informasi dan komunikasi yang bisa disarankan untuk jenjang SMA ini adalah model pembelajaran yang tentunya disesuaikan dengan tingkatan berpikir yang dimiliki individu pada usia ini. Di mana salah satunya adalah model-model pembelajaran yang mampu mengoptimalkan kemampuan kreativitas dan perasaannya. Kedua aspek ini sangat erat kaitannya dengan tingkatan berpikir yang dimiliki peserta didik jenjang SMA yaitu berada dalam tahaf berpikir abstrak.

Sebagaimana dari temuan menunjukkan bahwa dalam pelajaran matematika di SMU Mutthahari model pembelajaran berbasis komputer atau aplikasi hasil inovasi teknologi informasi dan komunikasi cukup menarik terutama pada bagian pada permainan dalam bentuk kuis dan tutorial yang diakhiri dengan latihan-latihan. Seperti dalam pelajaran kelompok eksak di antaranya matematika bahwa siswa 
terlihat lebih mampu menggabungkan kemampuan berpikir logik dan kreatif dalam mengembangkan pikiran-pikiran yang sifatnya discovery dan inquiry, (Karim, 2004). Sperry dalam Kapadia (2004: 54) menjelaskan sekali lagi bahwa orang yang menggunakan kedua sisi otaknya punya kekuatan mental yang baik. Maka orang harus menggunakan kedua sisi otaknya. Demikiann juga dalam hal aktivitas belajar kedua belahan otak terutama masa-masa peserta didik berada pada jenjang SMA harus lebih banyak dilatih untuk kesiapan profesi masa depannya berdasarkan konsentrasi disiplin ilmu yang akan ditempuh kemudian hari.

Model pembelajaran untuk jenjang SMU ini ditujukan untuk memunculkan sebuah kecepatan dan kreativitas belajar yang lebih mandiri terutama dengan mengandalkan kekuatan memori dan imajinasi baik itu imajinasi yang berasal dari kecerdasan visual dalam bentuk sajian visual animasi, imajinasi berdasarkan kecerdasan audio dalam bentuk sajian background suara dan jenis musik yang dikemas (Sabastian Bach), juga imajinasi berdasarkan kecerdasan kinestetiknya (DeForter, 2000) yang bisa disajikan melalui permainan dan simulasi yang didesain dalam model tersebut. Khusus untuk penumbuhan kekuatan kerja memori berdasarkan imageimage yang didesain dalam model pembelajaran ini penulis menetapkan nya sebagai suatu yang sangat dominan dalam kecepatan belajar. Dalam hal ini minimal peserta didik takjub, terstimulir dan muncul rasa ingin tahu bahkan ingin membuatnya sendiri.berdasarkan imajinasi sendiri. Imajinasi selama mengikuti model pebelajaran ini sangat kuat dalam mempengaruhi memori. Dalam hal ini Osho (1999: 137) mengemukakan bahwa" Jika kita melakukan eksplorasi memori maka kita perlu melakukan pengembangan imajinasiimajinasi yang kreatif misalnya dalam bentuk hal-hal yang mungkin terjadi yang sebelum tidak mungkin." Kontribusi dalam pembelajaran berbasis teknologi informasi dan komunikasi sebelumnya tidak mungkin untuk dikembangkan 
ternyata melalui temuan-temuan sebelumnya seperti yang dilakukan oleh ( Steven \& Trollip SR., 1984) dengan konsep dan desain model Computer Based Instruction), hal yang tidak mungkin ini ternyata bisa diwujudkan terutama yang berhubungan dengan pola-pola berpikir dalam belajar seperti latihan, pemetaan konsep, permainan, tutorial dan simulasi yang sebelumnya dilakukan dalam bentuk media-media nyata (realia).Shahib (2005) dalam hal ini menjelaskan bahwa:

"Seseorang mengatur dan memproses informasi sangat bergantung kepada kebiasaannya berpikir. Bagi seseorang yang biasa berpikir logis cara yang mudah menyerap informasi adalah disajikan dalam bentuk yang logis. Lain halnya dengan seseorang yang otak kanannya lebih dominan. Bagi mereka lebih senang mulai dari global lebih dahulu dan biasanya visualisasi yang disertai dengan imajinasi sangat berkesan bagi yang otak kanannya dominan."

Pendapat di atas dijadikan dasar dalam desain model multimedia interaktif ini yang harus menyajikan aspek belajar kognitif dan aspek kreativitas peseta didik jenjang SMU terutama sekali dalam melakukan pemecahan masalah. Dalam hal ini aspek kognitif dalam model ini masih perlu dikembangkan tentunya dengan proporsi yang seimbang berdasarkan tingkat perasaan dan gaya belajar yang telah terbentuk Dalam hal ini Shahib (2003:111) menegaskan kembali bahwa aspek "perasaan " memegang peran dalam proses pembelajaran yaitu suatu fungsi otak kanan. Kedua belahan otak dengan dua pola berpikir yang berbeda memungkinkan untuk dipadukan dalam model MMI untuk kelompok sosial atau eksak hal ini ditujukan kepada terciptanya imajinasi kreatif yang utuh. Salah satu bukti di lapangan menunjukkan bahwa dalam pelajaran kimia, di mana games atau permainan yang diiringi soal-soal latihan dan pembuktian ternyata mampu menarik perhatian siswa, seperti dalam materi SMU kelas I tentang unsur-unsur kimia 
dan pelajaran fisika tentang arus listrik. Fenomena yang terjadi pada kedua materi jika disampaikan dengan sajian model games dan simulasi ternyata cukup memberikan keterangan yang jelas mengenai bagaimana kemampuan kerja belahan otak kiri dan otak kanan ini saling mendukung dan mengisi kekurangan masing-masing. (Karim, 2004. Dapat disimpulkan bahwa model yang cocok untuk jenjang SMA ini adalah model tutorial, simulasi dan permainan yang didesain dalam bentuk MMI, di mana desainnya tidak lagi menyekat antara model tutorial, model permainan dan dan model simulasi. Jadi melalui sajian model ini masalah akselerasi siswa yang mengalami gangguan dengan pola berpikir tertentu bisa di bantu dengan sajian-sajian yang menjembatani kelanjutan kebiasaan ia berpikir apakah itu berpikirnya logik, global, atau keduanya. Berikut adalah visualisasi model pemikiran tentang model pembelajaran berbasis teknologi informasi dan komunikasi berdasarkan biologi komunikasi.

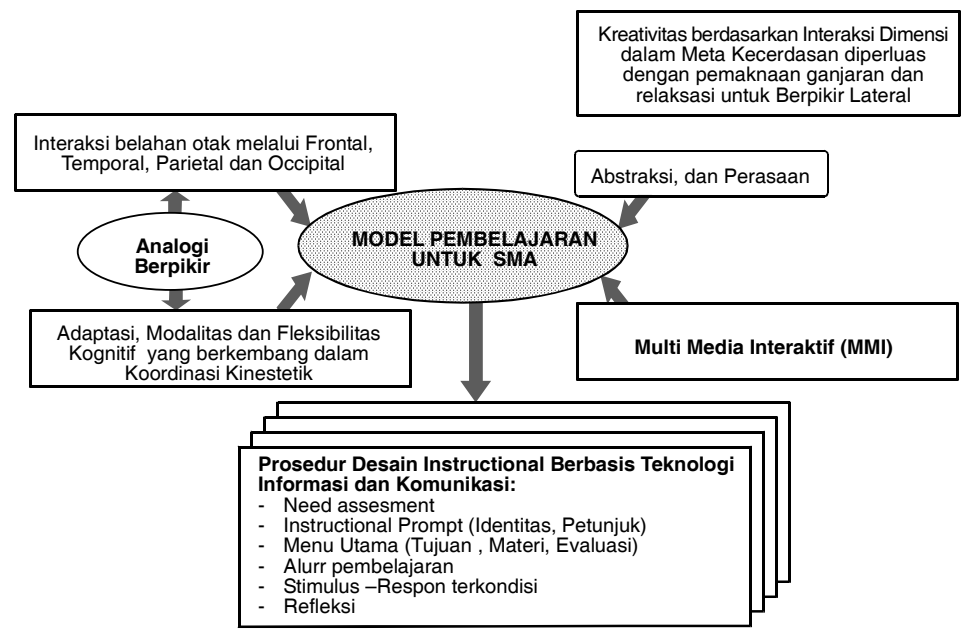

Gb. 4.57 Model Pembelajaran Jenjang Sekolah Menengah Atas dengan Pembelajaran Berbasis Teknologi Informasi dan Komunikasi Melalui Pemberdayaan Otak Peserta Didik (Hasil Riset, 2005) 
d. Model Pembelajaran Jenjang Pendidikan Tinggi berdasarkan Biologi Komunikasi

Model untuk jenjang PT ini, juga harus sudah mampu menyentuh aspek intuisi tentang apa yang dilihat (visual), dengan demikian kecepatan belajar akan lebih terbantu terutama yang akhirnya memberikan keyakinan terhadap sesuatu langkah-langkah pembuktian tentang hal-hal yang baru dipelajarinya. Model Tutorial yang dikemas juga harus mengadopsi konsep Lateral Thinking terutama untuk kelompok eksak sehingga stimulus aspek imajinasi dan kesan visual membantu dalam problem solving. Aspek-aspek persuasif dalam model tersebut juga mesti ada yang diperuntukkan dalam mengajak mahasiswa untuk berpikir logis dan rasional tentang fenomena yang disajikan dalam bentuk simulasi. Semua aspek yang mewarnai model pembelajaran yang dimaksud di atas prinsipnya menyajikan sebuah permasalahan yang didesain dalam bentuk latihan, tutorial, simulasi dan permainan. Menurut Shahib (2003: 100) pola pembelajaran yang disaji disebutnya dengan $P B L$ (Problem Solving Learning). Dalam PBL ini diberikan juga instrumen yang menuntut tanggung-jawab dan kreativitas peserta didik. Dengan demikian pada tahapan desain model antara dosen dan mahasiswa perlu melakukan kerjasama terutama dalam hal penerapan teknologi informasi yang selama ini bahkan jauh lebih cepat dan banyak dikuasai oleh mahasiswa sendiri ketimbang dosennya akan tetapi kontrol dan penanaman serta desain pendekatan dalam menerapkan model pembelajaran ini harus menjadi tanggung jawab dosen juga. Berdasarkan uraian di atas maka berikut ini adalah model pembelajaran berbasis teknologi informasi dan komunikasi untuk jenjang pendidikan tinggi ini mencakup seluruh model yang dikemukakan oleh Trollif \& Allesi (1992) yaitu drill, tutorial, simulasi dan Games yang diintegrasikan dengan berbagai aspek pendukung yang mencakup mapping concept, advance organizer knowledge, discoveryinqury, lateral thinking, persuasif, visual-audio imaging, yang 
dikemas dalam sistem ICT (Information Communication Technology) dengan alternatif sajian melalui prosedur sistem belajar jarak jauh seperti e-learning, teleconference, yang isinya bersifat problem solving dengan jalur pemecahan masalah diserahkan pada gaya dan tanggung jawab, keyakinan serta kemandirian belajar mahasiswa. Berikut adalah visualisasi model pemikiran mengenai model pembelajaran berbasis teknologi informasi dan komunikasi berdasarkan kontrol perilaku biologi komunikasi pada jenjang Pendidikan Tinggi.

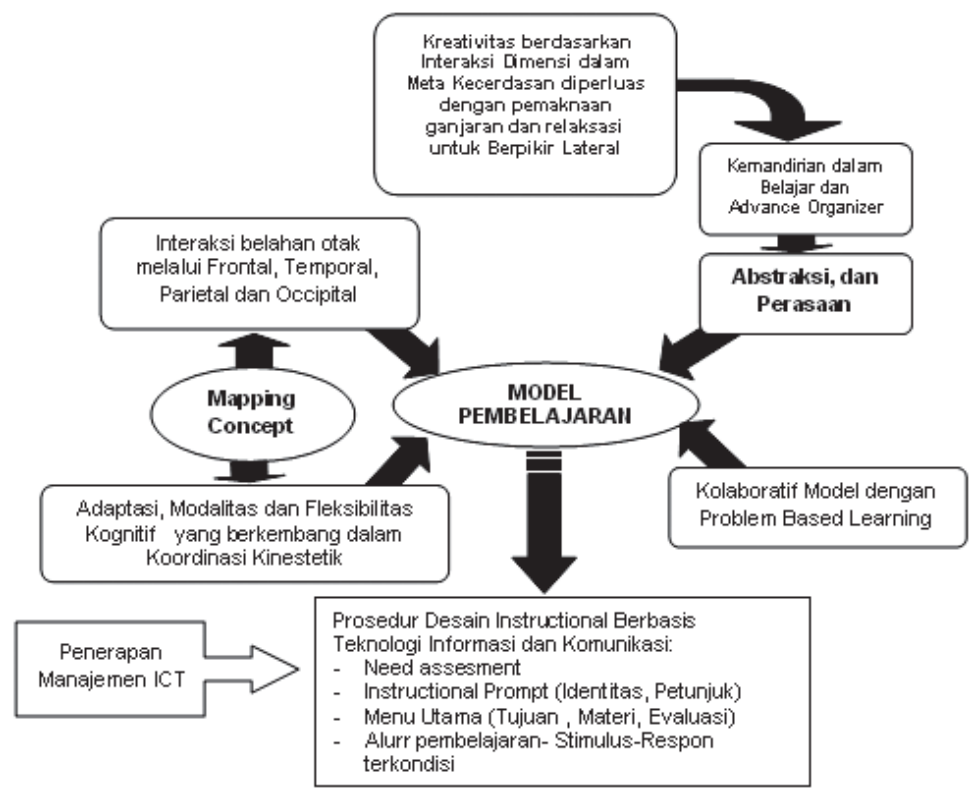

Gb. 4.58 Model Pembelajaran Jenjang Pendidikan Tinggi dengan

Pembelajaran Berbasis Teknologi Informasi dan Komunikasi Melalui Pemberdayaan Otak Peserta Didik (Hasil Riset, 2005) 


\section{E. KESIMPULAN DAN SARAN \\ Kesimpulan}

1. Pengemasan informasi dalam bentuk model pembelajaran berbasis teknologi informasi ternyata memberikan pengaruh yang positif dan signifikan terhadap kecepatan belajar peserta didik pada bidang eksakta dan sosial, mulai dari jenjang SD sampai PT yang dikontrol oleh perilaku biologi komunikasi.

2. Perilaku biologi komunikasi otak dalam aktivitas mengamati, merasa, memahami dan kecenderungan bertindak berlangsung pada bagian-bagian spesifik otak yaitu Prefrontal, Frontal, Parietal, Temporal, Parasagital, Central dan Occipital secara menyeluruh dengan kecepatan berbeda pada belahan otak kiri dan kanan baik sebelum maupun setelah menerima informasi pembelajaran berbasis teknologi informasi, terutama dalam melakukan transaksional sebagai wujud adanya interaksi antar sel dalam perspektif komunikasi.

3. Telaah perspektif keilmuan membuktikan perilaku biologi komunikasi dalam menjelaskan komunikasi intrapersonal dan interpersonal berdasarkan information processing melalui short term \& long term memory, sehingga tercipta kreativitas fisik, imajinasi, emosi, asosiasi, rasio-logika, dan perasaan yang memperlancar proses menerima, mentransformasi dan mengolah informasi pembelajaran berbasis TI sebagai salah satu bentuk brain based learning dalam akselerasi pembelajaran peserta didik jenjang SD sampai PT.

4. Model pembelajaran berbasis teknologi informasi dan komunikasi yang dikemas dalam bentuk latihan, tutorial, simulasi dan permainan dapat mengoptimalkan perilaku biologi komunikasi peserta didik dengan memperhatikan aktivitas bagian spesifik otak, khususnya untuk membantu kreativitas, adaptasibilitas, modalitas, fleksibilitas kognitif, imajinatif, berpikir lateral, mind mapping, discovery-inquiry, problem based learning, sentuhan musik, dan persuasif learning, pada peserta didik jenjang SD sampai PT bidang sosial dan eksakta. 


\section{Saran}

1. Saran Teoritis

Penelitian mengenai komunikasi, khususnya biologi komunikasi yang banyak berhubungan dengan bidang ilmu biologi dan kedokteran yang dititikberatkan pada komunikasi yang terjadi antar jaringan sel, organ tubuh dan sistem pengendali komunikasi manusia lainnya. Penelitian semacam ini belum banyak dilakukan, padahal telaah secara biologi, fisiologis, dan kedokteran sangat diperlukan dalam kajian lebih mendalam terhadap psikologi komunikasi, sosiologi komunikasi dan komunikasi instruksional, yang mampu mengarahkan individu untuk berperilaku secara rasional dan logis. Dengan demikian maka disarankan untuk meneliti aspek bidang ilmu biologi dan kedokteran dalam kaitannya dengan psikologi, sosiologi dan pendidikan baik secara kuantitatif maupun penelitian tindakan (action research) yang menggunakan pisau analisis teori-teori komunikasi, psikologi, sosiologi, biologi, kedokteran, budaya, dan teknologi informasi secara mendalam.

Dalam telaah keilmuan secara mendalam maka sebagaimana yang dimiliki oleh ilmu lain bahwa biologi komunikasi memiliki komponen-komponen yang masih dan perlu untuk di telaah atau dikaji kembali secara ilmiah sehingga mampu memberikan kontribusi bagi para ilmuan, akademisi, dan praktisi ilmu komunikasi dalam mengkaji secara mendalam mengenai komunikasi secara intrapersonal dan interpersonal serta menerjemahkan apa yang disebut dengan black box. Khusus kajian tentang Black box ini pada dasarnya adalah fenomena biologi yang selama ini hanya menjadi bidang garapan ilmu kedokteran atau medis padahal dalam telaah dan penerapan model-model komunikasi sangat diperlukan kejelasan atau proses seperti apa yang terjadi dalam black box tersebut. Jadi salah satu kemampuan biologi komunikasi yang diyakini berdasarkan hasil penelitian ini ditujukan untuk mampu menegaskan kembali bagaimana sebuah informasi diolah dalam otak manusia, yang dibuktikan melalui kajian fenomena fungsi 
kerja otak yang dimiliki oleh peserta didik mulai jenjang SD sampai PT.

\section{Saran Praktis}

Berdasarkan hasil penelitian ini maka secara praktis disarankan bahwa:

a. Para pendidik ketika melaksanakan pembelajaran berbasis teknologi informasi hendaknya mengenali dan memperhatikan perbedaan kecepatan peserta didik dalam melakukan aktivitas mengamati, merasa, memahami dan kecenderungan bertindak dengan mulai mengenali ciri dari bagian spesifik otak sebagai komponen komunikasi yang melakukan proses pengolahan informasi secara transaksional, interaksi dan perspektif keilmuan yang jelas.

b. Kepada para desainer model-model pembelajaran berbasis teknologi informasi dan komunikasi serta pendidiklainnya hendaknya memperhatikan aspek optimalisasi proses belajar peserta didik yang mencakup semua aktivitas belajar yang dikontrol oleh bagian spesifik otak sehingga model pembelajaran dalam bentuk CBI, CAl yang diproduksi mampu membantu akselerasi belajar peserta didik.

c. Dalam melakukan dan membudayakan inovasi teknologi informasi dan komunikasi yang melibatkan proses biologi komunikasi untuk membantu akselerasi pembelajaran berbasis otak hendaknya memperhatikan keterlibatan kajian perspektif ilmu-ilmu terkait seperti psikologi, biologi, pendidikan, komunikasi, budaya, kedokteran dan teknologi informasi itu sendiri sehingga diperoleh suatu validasi yang cukup mewakili untuk bisa disebarluaskan implementasinya.

d. Perilaku biologi komunikasi seperti proses asosiasi dan persepsi melalui dukungan short-term dan long-term memory hendaknya menjadi bahan pemikiran para desainer pembelajaran, pendidik dalam rangka mengembangkan polapola berpikir problem solving untuk mewujudkan keberhasilan akselerasi pembelajaran peserta didik yang dimulai dari memotivasi diri sendiri, keterampilan mencari memberi makna 
informasi pembelajaran, melatih mengungkapkan pengalaman sendiri hingga bagaimana mengatur dan merefleksikan keberhasilan belajarnya.

\section{DAFTAR PUSTAKA}

Applbaum L.Ronald \& Karl W. A. Anatol, 1974, Strategies for Persuasive

Communication. Ohio: Charles E. Merril Publishing Company.

Bigge, Morris, L., 1982, Learning Theorie for Teacher. Fourth Edition.

New York: Harper \& Row. Netherland : Elsevier Science B.V. all right

Reserved.

Chauchard, Paul, 1983, Bahasa dan Pikiran, Yogyakarta : Kanisius.

Christina, Bubb-Lewis, 1998, The Effect of Human-Computer

Communication Mode, Task Complexcity, and Desire for Control on

Performace and Discourse Organization in and Adaptive Task.

Dominion University.

Chriswell, L. Eleanor, 1989, The Design of Computer Based Instruction,

New York: Macmilan Publishing Company.

Chow, Vincent WS, 1997, Multimedia Tchnology and Application.

Singapore: Spring-Verlag Singapore Pte. Ltd.

Cohen, Vicki Blum. 1985. A Reexamination of Feedback In Computer

Based Instruction: Implication for Instructional Design. Educational

Technology Journal, New Jersey.

Criswell,L. Eleanor, 1989, The design of Computer-based Instruction,

New York: Macmilan Publishing Company.

Devito A. Jeseph, 1996, Komunikasi antar Manusia. New York: Harper

Collins Publisher. Inc.

Gagne, R.M, 1985, Essentials of Learning for Instruction, New York :

Dryden Press.

Ishak Abdulhak, dan Deni Darmawan, 2001, Model Komunikasi

Pembelajaran dalam Penyelenggaraan Perkuliahan Kelompok MKBS

di Lingkungan Fakultas IImu Pendidikan UPI, Bandung : Lembaga

Penelitian UPI, No: 060/23/2001, 13 Desember 2001.

Jalalludin Rakhmat, 1999, Psikologi Komunikasi, Bandung: Rosdakarya. 2004, Belajar Cerdas. Bandung : Brain Press-

Muthahhari. 
Jensen, Eric, 2003, Brain Based Learning, San Diego : The Brain Store. , 1996, Braion-based Learning, Del Mar, CA, USA: Turning Point Publishing.

Littlejohn W. Stephen, 1996, Theories of Human Communication, Belmont : Wadsworth Publishing Company.

Plomp, Tjeerd. Ely, Donald P. (Ed), 1996, International Encyclopedia of Educational Technology, $2^{\mathrm{ed}}$, Cambridge: Pergamon.

Pope, Geoffrey, 1984, Antropologi Biologi, Jakarta : Rajawali

Rakhmat, Jalalludin, 2003, Belajar Cerdas, Bandung : Cortext Muthahhari. Press.

Ritzer George, 1992, Sociological Theory, $3^{\text {ed }}$, New York: McGraw-Hill, Inc.

Roger M. Everett, 1983, Diffussion of Innovation, $3^{\text {ed }}$, London: The Free Press Collier Macmillan Publisher. , 1986, Communication Technology: The New Media and Technology. London: Collier Macmilan Publishers.

Shahib, Nurhalim, 2003, Mengenal Allah dengan Mencerdaskan Otak Kanan, Bandung: Media Pustakatama.

Stanger, Ross \& Solley, M. Charles, 1970, Basic Psychology: A Perceptual-Homeostatic Approach . Bombay -New Delhi: Tata Mc Graw-Hill Publishing Co. LTD. 